\title{
COMPARATIVE ANALYSIS OF PUTIN- \\ MEDVEDEV FOREIGN POLICY MAKING: SYRIA AND LIBYA CASE
}

\section{Muhammet Koçak, PhD}

Florida International University

Mkoca001@fiu.edu

https://orcid.org/00oo-0002-6448-9250

doi: $10.31834 /$ ortadoguvegoc.1009090

Makale Türü / Article Types: Araştırma Makalesi / Research Article

Geliş Tarihi / Received: 13 Ekim / 13 October 2021

Kabul Tarihi / Accepted: 21 Aralık / 21 December 2021

Yayın Tarihi / Published: Aralık / December 2021

Yayın Sezonu / Pub Season: December / Aralık

Atıf / Cite: Koçak, M. (2021). Comparative Analysis of PutinMedvedev Foreign Policy Making: Syria And Libya Case. Ortadoğu ve Göç, 11(2). ss. 190-222

Intihal / Plagiarism: Bu makale, en az iki hakem tarafından incelendi ve intihal içermediği teyit edildi. / This article has been reviewed by at least two referees and checked via a plagiarism detector. Copyright $\odot$ Published by Kilis 7 Aralık Üniversitesi, Lisansüstü Eğitim Enstitüsü, Kilis, 79000 Turkey. All rights reserved 


\begin{abstract}
This article explains the shift in Russia's foreign policy strategy towards the Middle East. Particularly, it aims to address the question of why Russia supported the UNSC Resolution 1970 towards Libya in 2011 but refused to cooperate with the West in Syria. In this article, it is argued that the West's use of the authorization of the no-fly zone as a green light for military intervention in Libya paved the way for Russia's obstinacy in Syria. To test this hypothesis, this article focus on the foreignpolicy decision-making mechanism in Russia regarding these two events. In this article two decision-making processes are compared to provide an alternative explanation of Russia's Middle Eastern policy. This article contributes to the existing literature on Russian foreign policy and Foreign Policy Analysis literature.
\end{abstract}

Keywords: Russian Foreign Policy, Syrian Civil War, Arab Uprisings, Libyan Civil War.

\title{
PUTIN VE MEDVEDEV'IN DIȘ POLITIKALARININ KARŞILAȘTIRMALI ANALIZi: SURIYE VE LIBBYA ÖRNEĞi
}

Öz

Bu makale, Rusya'nın dış politika stratejisindeki Orta Doğu'ya yönelik değişimi açıklamaktadır. Özellikle, Rusya'nın 2011 yılında Libya'ya yönelik 1970 tarihli BMGK Kararını neden desteklediği ancak Suriye'de Batı ile işbirliği yapmayı reddettiği sorusunu ele almayı amaçlamaktadır. Makalede Batı'nın uçuşa yasak bölge yetkisini Libya'ya askeri müdahale için yeşil ışık olarak kullanmasının Rusya'nın Suriye'deki inatçılığının önünü 
açtığını savunulmaktadır. Makale, bu hipotezi test etmek için, bu iki olayla ilgili olarak Rusya'daki dış politika karar alma mekanizmasına odaklanıyor. Makalede iki karar verme süreçleri ve Rusya'nın Orta Doğu politikasına alternatif bir açıklama sunmak için karşılaştırılmaktadır. Bu makale, Rus dış politikası ile ilgili mevcut literatüre ve Dış Politika Analizi literatürüne katkıda bulunmaktadır.

Anahtar Kelimeler: Rus Dış Politikası, Suriye İç Savaşı, Arab Ayaklanmaları, Libya İç Savaşı.

\section{Introduction}

Libya and Syria were two of the allies of the USSR's during the Cold War. During the 1990s, however, Russia did not establish a strong presence in the Middle East because it lacked the grand ambitions of the USSR, and bogged down with its own domestic political and economic problems. Fast forward to 2021, Russia established a military base and began to control Syrian airspace. Russia remains the key external actor in the conflict as the chief supporter of the Assad regime along with Iran. Besides providing a diplomatic umbrella to the Assad regime through its seat in the UNSC, Russia also provides military support to the regime through aircraft, military advisors, soldiers, and defense systems. Libya, where Russia enabled a military intervention in 2011, was also included in the area where Russia projected power in 2015. Through its support to Khalife Hafter, who was a Gaddafi-era military commander exiled in the US for decades, Russia has been able to shape the course of events in Libya. It also established military presence in Libya through military advisors and mercenaries. Russia's presence in Libya enables Russia to establish a foothold in the Mediterranean and Africa. 
This article revisits the time when Russia's Middle Eastern Policy in particular and its foreign policy, in general, had a significant turnaround. In 2011-12, Russia positioned itself with the counter-revolutionary forces against the backdrop of a revolutionary wave that came with the Arab Uprisings. Under Medvedev, Russia enabled a military operation to Libya through abstaining from the UNSC Resolution 1970 regarding a no-fly zone. In the following process, however, Russia's foreign policy strategy towards the Middle East-North Africa region took a different path as Russia became one of the chief guardians of the counterrevolutionary regimes in the Middle East.

I argue that the abuse of Russia's green light for no-fly zone by the Western powers through a large scale invasion in Libya in 2011 played a significant role in Russia's preference of rather confrontational path in its foreign policy. Using Margarett Hermann's decision-unit framework (Hermann, 2001). I will examine Russia's decision-making processes in Libya and Syria. The decision-unit framework helps analyzing the way a particular state formulate a foreign policy towards in a point of decision. My analysis demonstrates that the segments in the Russian foreign policy decision-making process that was not pleased with the fact the West abused Russia's green light for a no-fly zone in Libya through a full-blown military intervention, which was finalized with the lynching of Libya's Gaddafi, pushed for a change of course in Russian Foreign Policy.

A review of the literature on Russian foreign policy will follow this section. Then, I provide a short analysis of the theoretical framework I utilize for this research. In the following section, I analyze Russia's decision-making process regarding a possible international military intervention in Libya and Syria 
respectively. I conclude this article with a conclusion part where I discuss the findings of this article.

\section{Literature Review}

There is a rich literature on Russian foreign policy because the Soviet Union was one of the two superpowers during the Cold War and Russia remains an important military power in the post-Cold War era. Russia's emerging aggression that first manifested itself in Georgia in 2008 and then continued in Ukraine and Syria gave an additional boost to this scholarship. In this section, I review the literature that attempts to explain the aggressive turn in Russian foreign policy. Then, I suggest how the analysis in this article could contribute to the existing scholarship.

Realism dominated the Cold War era thinking on Russian foreign policy (Kanet, 2012). According to such a view, Russia has fixed national interests, which are determined by conditions beyond the control of Russia. For example, Mearsheimer argues that Russia's annexation of Crimea in 2014 was simply an attempt to counter the NATO enlargement (Mearsheimer, 2014, p. 78). It is possible to give more examples of this line of thinking from the literature (Lynch, 2011; Feinstein and Pirro, 2021). Realism provides a simple explanation for the changes in foreign policy strategies of different states based on the changes in balance of power. In this approach, various external factors, such as the emergence of other great powers, changing balance of power, and changes in the system influence Russia's foreign policy actions. The fundamental deficiency of Realist thinking is its tendency to ignore internal factors. Russia's domestic political structure, threat perceptions, identity, and economic structure do play a significant role in Russia's foreign policy actions. For example, Realist theories do not explain why 
Russia sees the West as more of a threat than China with whom Russia shares a long border and in competition in Central Asia and other places (Ziegler, 2012). Kropatcheva argues that through a neoclassical realist account it is possible to discuss both internal factors, such as Russia's pursuit of status and external factors, such as the changes in the balance of power, that influence Russia's foreign policymaking (Kropatcheva, 2012, p. 38). Such a framework still does not allow examining wider normative dimensions with its acceptance of material power balance as the main tenet of the international system. In addition to that, neoclassical realism considers the economy within the framework of state resources with its state-centric approach.

Following the end of the Cold War, the constructivist scholars successfully attacked the epistemological foundations of realism and paved the way for the inclusion of history, culture, and ideas in the discussion of foreign policy (Kanet, 2012, p. 394). Most studies that focus on ideational factors problematize Russia's perception of the West. In her book, for example, Clunan demonstrates that the West is an important element for the most significant self-images of Russia (Clunan, 2009, p. 62). For instance, Hopf argues that discursive exercises that consider Crimea a part of Russia played a significant role in facilitating Russia's decision to annex Crimea (Hopf, 2016). Forsberg et al. argue that status concerns played a significant role in the aggressive turn in Russia's foreign policy (Forsberg et al. 2014). Similarly, Larson and Schevchenko argue that the West's refusal of Russia as part of the West played a significant role in Russia's assertive foreign policy (Larson and Schevchenko, 2010, p. 67). Beyond this spectrum, there are those scholars with alternative frameworks focusing on various aspects that might influence Russian foreign policymaking. Among these, Toal uses critical 
geopolitics (Toal, 2017), and Morozov uses a post-structuralist framework (Morozov, 2015). There is a well-established literature on Russian strategic culture (Snyder, 1977; Ermath, 2009). While the contribution of these works is undeniable, they do not aim to bring about a wholesome explanation of Russian foreign policy or Russia's place in the international order.

Due to the dynamism, he brought to the Kremlin, Putin became the focus of several analyses in the literature. Hill and Gaddy's 2013 book where the authors delineate his identity and explain his impact on Russian foreign policymaking is one of the more popular of these works (Hill and Gaddy, 2013). However, as Lynch correctly notes, these studies tend to ignore the fact that some tendencies attributed to Putin are shared by a wide spectrum of the Russian political elite (Lynch, 2009, p. 62). Another important potential deficiency commonly seen in these works is that they tend to ignore the relevance of external dynamics in pushing Russia in certain directions. Therefore, it is possible to raise questions about the explanatory power of these works from a rather Realist angle.

Focusing on Russia's domestic politics as an important dynamic in Russian foreign policymaking is another important part of the literature. I also focus on the interpretations and reflections of the Russian foreign policy decision-making elite could contribute to the existing scholarship in this article. Cadier and Light, for example, argue that domestic regime consolidation concerns play a significant role in setting Russia's foreign agenda (Cadier and Light, 2015, p. 205). Similar to the argument put forward in this article, many analyses focus on the interests of Russia's different political elite groupings in determining Russia's foreign policy. For instance, Tsygankov attributes the changes in Russian foreign policy to the increasing or decreasing of the impact of groups of 
political elites (statists, westernizers, and civilizationists) on the foreign policymaking process in Russia (Tsygankov, 2016, p. 9). Bremmer and Charap bring a more functional classification of Russia's political elite as technoctats, liberals and siloviki (Bremmer and Charap, 2007, p. 85). This paper takes benefit from this classification in an attempt to explain the infighting over Russia's foreign policy towards the Middle East.

\section{Analytical Framework}

This article attempts to take benefit from the Foreign Policy Analysis (FPA) literature to analyze the impact of foreign policy decision-making processes on Russian foreign policy strategy. Through a state-level analysis, I focus on how the changing impact of different political factions in the foreign policy making and the changing nature of the decision-making processes affect the outcome of the decision. Margaret Hermann's decision-unit analysis conceptualizes a model, through which the 'decision-unit framework' can be determined and the effects that these kinds of decisionmaking units can have on governments' foreign policy behaviors can be tested (Hermann, 2001). In her work she shows how whether one person, a group or a coalition of autonomous actors make the decision impact the decisionmaking process.

The FPA literature dates back to the Cuban Missile Crisis, which was a turning point as it systematized the efforts to look inside the 'black box' and consider unit-level instead of system-level dynamics. One of the first attempts in this research agenda was Ole Holsti's 'The 1914 Case,' which examined political decision-making in moments of stress (Holsti, 1959, p. 365). Graham Allison took this agenda one step further and developed this approach by focusing on bureaucracy in his 
book, 'Conceptual Models and the Cuban Missile Crisis' (Allison, 1969). Irving Janis examined the impact of the dynamics of group decision-making on foreign policymaking (Janis, 1972). Operational Code Analysis, which was formulated by Nathan Leites in his study of Bolshevism (Leites, 1953) has been used to examine the way key decision-making group perceives the world and responds to it. Lastly, Poliheuristic Theory was developed by Alex Mintz to examine decision-making processes through cognitive shortcuts (Mintz, 2005).

Hermann utilizes the findings of Janis regarding the psychological variables affecting the decision-making process (Hermann, 2001, p. 51), while it gives credit to Graham Allison in initiating the studies on decision-making units (Hermann, 2001, p. 49). The decision-unit framework is the consequence of decades of research. Margaret Hermann and Charles Hermann in their 1982 article 'A look inside the black box: Building a Decade of Research' pointed out that the literature of foreign policy analysis was mature enough to produce a model, which can analyze what is inside the black box (Hermann \& Hermann, 1982). They examined how the decision-making mechanism enables the beliefs of actors to affect the final decision to be determined (Hermann \& Hermann, 1982, p. 2). In 1987, Hermann, Hermann, and Hagan presented their 'ultimate decision-making unit analysis' that enables to analyze of the impact of the bureaucratic structure of decision-making on foreign policy decisions (Hermann, Hermann \& Hagan, 1987). The model achieved its final stage and transformed into a theoretical framework in 2001, with the article of Margaret Hermann: 'How Decision Units Shape Foreign Policy' (Hermann, 2001).

The main feature of the 'Decision-unit framework' is the authoritative decision-making unit, which refers to 'an 
individual or a set of individuals with the ability to commit the resources of the society and, when faced with a problem, the authority to make a decision that cannot be readily reversed' (Hermann, 2001). This model detects the type of decision unit that emerges in response to a decisive moment and examines the impact of the type of unit on the decision (Hermann, 2001, p. 51-52). The decision-making units are 'predominant leader', "single group" and "coalition of autonomous actors" (Hermann, 2001, p. 57-58). By applying this model, it is possible how the 'ultimate decision-making unit' affects the foreign policy outcomes and how much capacity does the 'ultimate decision-making unit' has to commit or withhold the resources of the state for external affairs (Hermann, 2001, p. 58-60). Figure 1 shows the three phases of the 'decision-unit framework' (Hermann, 2001, p. 52).

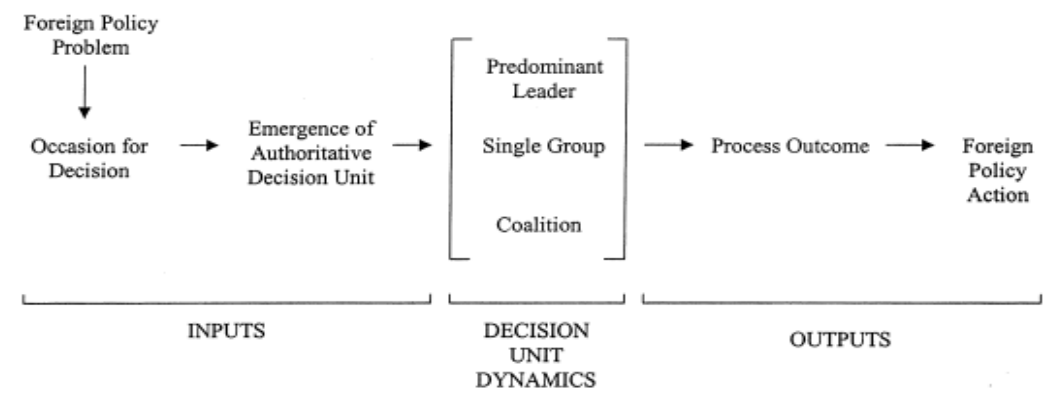

Figure 1: Overview of the 'decision-unit framework' (Hermann, 2001).

The first phase, 'input', starts with the emergence of a foreign policy problem. This creates the 'occasion for decision' for the state and the 'authoritative decision-making unit' emerges to deal with the problem. Then the problem is evaluated within the decision-unit dynamics. An instant solution or progressive set of solutions emerge as a consequence of this process. The three authoritative decision-making units of Margaret 
Hermann's decision-unit analysis are: 'predominant leader', 'single group', and 'coalition of autonomous actors'. A 'predominant leader' emerges when there is only one person effective in the decision-making process. It refers to a structure where there is somebody on top of the government, like Gaddafi's Libya. In the case of 'single group', a group of individuals is involved with the decision as in the case of the Soviet Politburo. Lastly, the 'coalition of autonomous actors' is the case where multiple actors are involved with the decision and none of them can rule the resources of the government, as in today's UK. The decision unit framework offers key contingencies that enable us to analyze why different decision-making units produce different outcomes. The key-contingency for a 'predominant leader' is the 'sensitivity of the leader'; for 'single group' it is the 'techniques used to manage disagreement and conflict'; for 'coalition of autonomous actors' it is the 'nature of rules and procedure guiding interaction' (Hermann, 2001, p. 64-65). 'The decisionunit framework' helps to infer the policy outcome based upon the authoritative decision-making unit, which prevails upon the occasion for decision. Table 1 shows the six categories of process outcomes. Table 2 shows the guideline to be used to choose the authoritative decision-making unit. 
Table 1: Process Outcome (Hermann, 2001).

\begin{tabular}{|c|c|c|}
\hline \multirow{2}{*}{$\begin{array}{l}\text { Range of } \\
\text { Preferences } \\
\text { Represented } \\
\text { in Decision }\end{array}$} & \multicolumn{2}{|c|}{ Distribution of Payoffs } \\
\hline & Symmetrical & Asymmetrical \\
\hline One Party's & $\begin{array}{l}\text { Concurrence } \\
\text { (All own decision; see } \\
\text { decision as final; move } \\
\text { to other problems) }\end{array}$ & $\begin{array}{l}\text { One Party's Position Prevails } \\
\text { (Only one party owns decision; } \\
\text { others monitor resulting action; } \\
\text { push for reconsideration if } \\
\text { feedback negative) }\end{array}$ \\
\hline Mixed Parties' & $\begin{array}{l}\text { Mutual Compromise/ } \\
\text { Consensus } \\
\text { (Members know got all } \\
\text { possible at moment; } \\
\text { monitor for change in } \\
\text { political context; seek } \\
\text { to return to decision } \\
\text { if think can change } \\
\text { outcome in their favor) }\end{array}$ & $\begin{array}{l}\text { Lopsided Compromise } \\
\text { (Some members own position, } \\
\text { others do not; latter monitor } \\
\text { resulting action and political } \\
\text { context, agitating for } \\
\text { reconsideration of decision) }\end{array}$ \\
\hline No Party's & $\begin{array}{l}\text { Deadlock } \\
\text { (Members know no one } \\
\text { did better than others; } \\
\text { seek to redefine the } \\
\text { problem so solution or } \\
\text { trade-offs are feasible) }\end{array}$ & $\begin{array}{l}\text { Fragmented Symbolic Action } \\
\text { (No members own decision; } \\
\text { seek to change the political } \\
\text { context in order to reconstitute } \\
\text { decision unit) }\end{array}$ \\
\hline
\end{tabular}

Table 2: Determining the Authoritative Decision-Making Unit (Hermann, 2001).

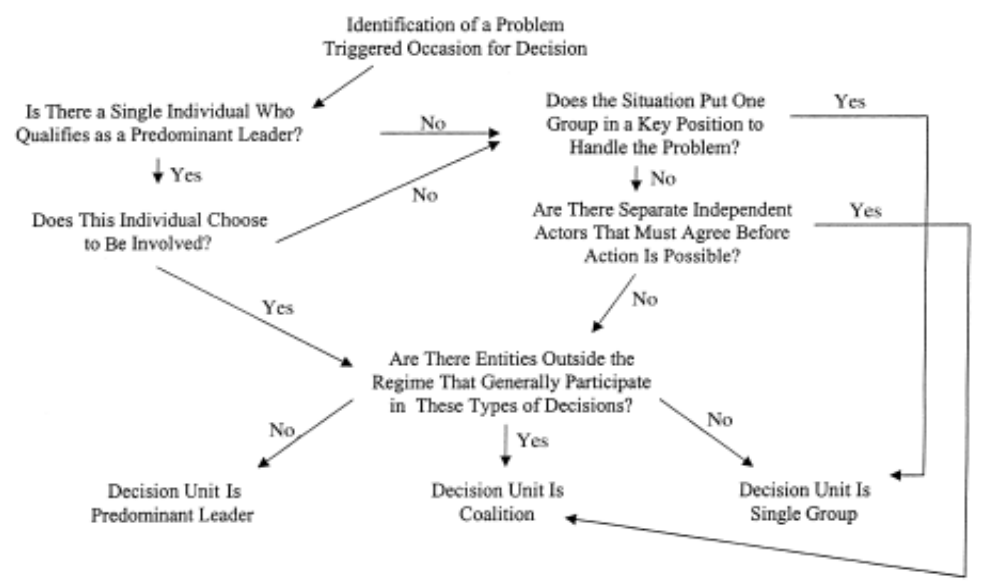

In this work, the focal point is the foreign policy conduct regarding the intervention in Libya under Medvedev's presidency and the intervention in Syria under Putin's presidency. I analyze and compare the foreign policy decisionmaking processes in the case of Libya and Syria. For each decision, I first determine the authoritative decision-making 
unit based upon the guideline shown in Appendix A, then I evaluate the dynamics of the foreign policy conduct. Finally, the process outcome will be evaluated.

\section{The Elements of the Russian Foreign Policy Decision Making}

\section{Mechanism}

In this section, I analyze Russia's foreign-policy decisionmaking dynamics. This section serves as a transition to the main part where Russia's foreign policy towards the Middle East-North Africa region will be discussed. I argue that despite the centralization of power as a predominant character of Russia's decision-making dynamics, elite groupings are vying for influence in foreign policy conduct in Russia. These groupings balance the impact of the President, who may belong to one of these groupings, and create an advantage to their preferences.

The centralization of power is the most predominant character of Russian governance. President is the sole authority regarding foreign policy matters according to the Russian Constitution (Article 86 of the Russian Constitution). Even though the Russian Constitution was written in 1993, this practice has been prevalent in Russian polity for centuries as can be seen in the examples of Peter the Great and Stalin. Putin utilized his power to restore order in Russian Federation, revitalize its military and economic power, and ensure the rule under a strong central government in Russian Federation. He also accumulated personal political capital so much that when Dmitri Medvedev was elected President in 2008, he was seen as Putin's puppet (Duncan, 2013). However, as further analyzed below, Medvedev also utilized his Presidential authority. 
The Presidential authority in Russia, however, is not without qualifications. The bureaucratic institutions inside Kremlin, as well as informal groupings, also play a major role in foreign policymaking. Although there are different versions of classifications of the groupings inside the Kremlin, three major groups stand out: Siloviki (sila means power in Russian), Liberals, and Technocrats. Siloviki refers to the influential civil servants in the security establishment, who come from the military or KGB background. Putin's coming to power increased the influence of Siloviki at the expense of Liberals and Technocrats (Renz, 2006). Distinctive characteristics of Siloviki can be summarized with their hawkish attitude towards the West, Cold War mentality, and that most of them owe their political carrier to Vladimir Putin.

Within the Russian bureaucracy, Security Council ensured the Siloviki control over Medvedev's decisions. The Security Council of the Russian Federation was one of the elements of foreign policymaking in the Russian Federation. It is made up of handpicked top-level bureaucrats by the president and its function is to contribute to the handling of state affairs by the president including foreign policy conduct. Putin was attending the meetings of the Security Council of Russia along with other bureaucrats, mostly Siloviki. Therefore, the Security Council of Russia was more or less a forum, which ensures the Silovik control over the president's policies. Technocrats are composed of specialists in the Kremlin. Medvedev was among the most important members of this clique (Bremmer and Charp, 2007, p. 85). The Technocrats' role in the Putin era has been to execute the decisions of Vladimir Putin and other Silovik bureaucrats. Liberals are composed of the Westernminded liberal bureaucrats of the Kremlin, who were brought into top positions in the Kremlin by Yeltsin. 'The liberals, led by Economic Development and Trade Minister German Gref and 
Finance Minister Aleksei Kudrin, are defined by their shared approach to economic policy, which, although significantly more interventionist than Western liberalism, is more marketfriendly than the philosophies of their rivals' (Bremmer and Charap, 2007, p. 85). However, they remained loyal to the Putin-era bureaucrats who ended up becoming effective in Kremlin (Reder, 2013, p. 10).

\section{Russia`s Foreign Policy in Syria and Libya}

This section analyzes changes Russia's foreign policy towards the Middle East-North Africa region using Hermann's decisionunit framework. I first look at the case of Libya where, a decision taken by a 'coalition of autonomous actors' resulted in Russia's green light to a no-fly zone in Libya. Then, I look at the case of Syria, where Russia did not cooperate with the West and prevented efforts for a UN-mandated military intervention. Unlike the first one, this decision was taken by Putin who appeared as the 'predominant leader.' I argue that the failure of the first course of action in securiin Russia's interests played a significant role in bringing the change in Russia's foreign policy.

\section{Authorization of No-Fly Zone in Libya}

Libya was one of the most important decision points for Medvedev, who became President in 2011. Upon the human rights violations committed by the Gaddafi regime, the international community led by France and the US pushed for military intervention in Libya. The intervention could be justified on human rights grounds although it was doubtful whether an intervention could bring stability to Libya or whether Russia could pursue its interests through a new form of government. In such a scenario, the Technocrat and Liberal factions within the Kremlin could be expected to opt for 
intervention while the Siloviki would oppose going with the West. This situation played out through two decision-making processes. At first, Russia partially agreed to the measures against Libya. In the second round, Russia enabled a Western intervention through a no-fly zone. In this section, these two decision-making processes will be discussed using the decision-unit framework.

Starting from January 2011, opposition groups began to protest the Gaddafi government 'over the late completion of government subsided housing (Abdel-Baky, 2011). These protests were met with the harsh reaction by disproportionate government forces, which caused the deaths of tens of protesters. The situation quickly turned into a civil war. Meanwhile, the opposition forces founded the National Council to provide a political mechanism to the revolution (Al-Jazeera, 2011). The magnitude of the civil war was not realized in the first place because of the simultaneous events in Egypt, where Mubarak was toppled. Libyan regimes' using mercenaries and air bombings against the civilian population demonstrated that there would be no smooth transition to a new regime in Libya, hence the attention of the international community.

When the Libyan civil war broke out and attracted the attention of the international community, Medvedev faced a dilemma between cooperation with the West in Libya and preventing an international military action. On the one hand, preventing the efforts for action would place Russia in a position of an uncooperative actor when human rights issues are at stake, something the Liberals of the Kremlin are sensitive about. Medvedev commented that what happened in Tunisia should be a lesson for all the governments about what would happen when they are not sensitive to the public demands (Medvedev, 2011C). On the other hand, siding with 
the West could mean increasing the Western influence in the Middle East, if one sees international politics as a zero-sum game, which the Siloviki do. Moreover, if Russia gave its full consent to the West and a regime change occurs in Libya it was not guaranteed that the new regime would act per Russian interests in the region. Putin was also wary of the rise of extremism in the Middle East (Rossiya 24, 2011).

In collaboration with two liberals: Foreign Minister Lavrov and Russian ambassador to UN Vitaly Churkin; Medvedev worked out the Russian decision to support the West in Libya. By voting 'Yes' for the UN Resolution 1970, Russia approved the referring of Libya to the International Criminal Court, imposing a travel ban to and freezing the assets of Libyan rulers (Security Council of Russia, 2011). While Russia approved sanctions on Libya, it did not cooperate with the West on military intervention, which was not enabled by UN Resolution 1970. While it was not expected from Siloviki to support putting sanctions on a friendly leader, it can be suggested that the Medvedev and Liberals would not be in favor of putting such a provision that would prevent the resolution of the conflict on a large scale.

Whose decision was that? As stated earlier, Medvedev had the presidential power to realize his foreign policy agenda. However, he was put into the president's office by Putin so his decisions were being taken in collaboration with the Siloviki faction. Therefore, to understand whose decision was Libya, we need to consider the agenda of the Presidency and the Secuirty Council. The issues that were covered in the Security Council of Russia when the agenda of foreign policy was Libya were not particularly related to the decision on Libya. In February 2011 the Security Council of Russia discussed the NATO-Russia relations, Patrushev's visit to Poland, and Russian-American cooperation in regional security (Security 
Council, 2011). Thus, it can be stated that Dmitri Medvedev, decreased the effect of the Siloviki faction in the decisionmaking process, by avoiding discussing the matter in the Security Council of Russia. On the other hand, the Ministry of Foreign Affairs, which is known to work in tandem with Medvedev played a significant role in the process (Reder, 2013, p. 247). However, as Reder argues, Putin was involved in the decision-making process but Medvedev's liberal temperament could have precluded Russia's decision (Reder, 2013, p. 247). Therefore, there appeared two schools of thought in the Kremlin regarding how to act towards the situation in Libya. First, the Siloviki, who were distrustful about the intervention by the West and considered a scenario, which would harm Russian interests in the region. This decision, therefore, could be an example of 'lopsided compromise', where 'one party's preferences have prevailed but they have yielded a little to allow the others in the decision process to save face' (Hermann, 2001, p. 69). While Medvedev got his preferences prevailed by voting yes on UNSC Resolution 1970, he have compromised the military option by then. 
Table 3: Application of 'Decision-Unit Framework' to Libya case (Resolution 1970)

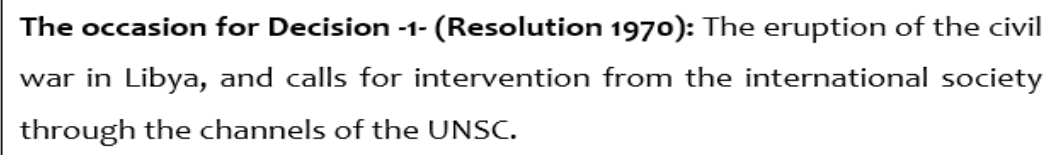

Authoritative Decision-Making Unit: 'coalition of autonomous actors' (Siloviki faction for non-involvement into Libya and no support to West and Liberals plus Medvedev for coercive action to stop the violence)

Process Outcome: Lopsided Compromise (Russia supported the measures on Gaddafi but secured a provision preventing military intervention)

Upon the continuation of violence in Libya, the UNSC convened again, now for imposing a no-fly zone in Libya. In this second decision-making process, Russia supported the Western coalition with an abstention in the UNSC resolution 1973. This situation qualifies to be a situation which is described by Hermann as 'one party's position prevails', where 'some of those in the decision process have their preferences accepted as the choice' (Hermann, 2001, p. 69). Hermann also suggests that 'if the feedback is negative, the members of the decision unit whose ideas were not represented in the action can be agitators for different or further action' (Hermann, 2001, p. 71). It was not a surprise that Putin was not feeling happy that his preferences were not taken into consideration while the decision on Libya was being taken. That's why, according to the 'decision-unit framework', a further agitation could have been expected by him, which came with his push for the reconsideration of legal base regarding the place of the 
Security Council of Russia in the foreign policy decision making which makes it way more effective and Putin's firm policy regarding Syria.

Table 4: Application of 'Decision-Unit Framework' to Libya case

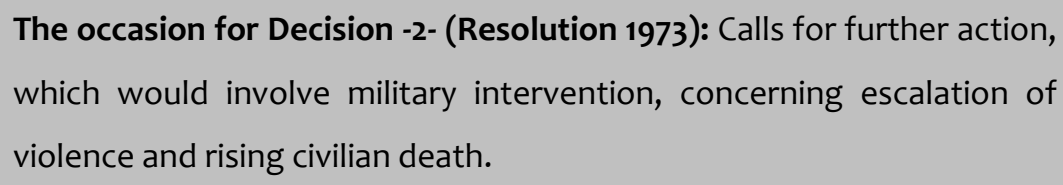
which would involve military intervention, concerning escalation of violence and rising civilian death.

Authoritative Decision-Making Unit: 'coalition of autonomous actors' (The two actors in coalition holding their stance)

Process Outcome: One Party's Position Prevails (Medvedev's preferred course of action prevails. The Siloviki faction's potential influence is realized after the foreign policy action in amending the constitution in favor of the effect of the Siloviki institution -Security Council- on foreign policy and in the discourse of Putin afterward.)

To sum up, the Siloviki faction and Medvedev were almost equally influential in the decision-making process. While Medvedev had the presidential powers, the Siloviki faction had the bureaucratic control mechanism, and Putin, who had still been the most charismatic leader in Russia. The decisionmaking process, therefore, has developed with respect to this power balance. The UNSC Resolution 1970 reflected this power balance with a situation of lopsided compromise as described by Hermann. In the UNSC Resolution 1973, however, the power of Siloviki would appear in further agitations and reactions, which revealed itself in the constitutional change, 
which increased the Siloviki control over foreign policy and the foreign policy-making regarding Syria.

\section{Russia`s Unilateral Initiative in Syria}

Between late 2010 to early 2012, a wave of grassroots protests across the Arab World seriously threatened autocratic regimes. The protests achieved significant success in their call for reforms in several countries and regime change in multiple countries. In Syria, however, the protests evolved into a largescale humanitarian calamity with the regime's reckless torturing and murdering of civilians, the involvement of several states and the non-state actors, and the emergence of radical groups. Despite the expectations for the contrary, the Syrian Baath regime led by President Bashar Assad did not fall within months (Ataman, 2012, p. 35). In a few years, Syria has become a battleground where a balance of terror was established in which none of the two sides of the conflict could prevail over the other, eventually producing a prolonged civil war where several domestic, regional, and global conflicts were fought through proxies. One of the major reasons why the Syrian regime could resist the opposition and has been able to pursue a bloody battle against its citizens is the Russian support behind the Assad regime. Along with Iran, Russia became the most important ally of the Assad regime. Syria has taken benefit from the policy of Russia, which pursues influence in the Eastern Mediterranean through Syria. Russia supported Syria against the Western countries even when the chemical weapons use became apparent in August 2013. In this part I discuss how the decision did regarding Syria was taken in the Kremlin bureaucracy, and why Russia chose to support the Assad regime.

When the Arab spring first sparked in Syria within the beginning of 2011, Assad suggested in a rare interview he has 
given to Wall Street Journal: 'protests in Egypt, Tunisia and Yemen are ushering in a "new era" in the Middle East, and that Arab ruler would need to do more to accommodate their people's rising political and economic aspirations' (Solomon and Spindle, 2011). However, when the protests began in March 2011 he did not act as such and chose to suppress the rebels with brutal force. Starting from June 2011, the tensions in Syria have escalated and the Syrian regime began to use heavy machinery, tanks, and planes. The spread of violence in Syria raised the expectations for military intervention, an example of which was seen in Libya.

Being amongst the five permanent members of the UNSC, Russia was in a key position to resolve the crisis. Regarding the aftermath of the decision-making process (Libya) which concluded with the situation 'one party's position prevails', Hermann suggests that: 'those members of the decision unit whose positions are not represented in the outcome can become agitators for different or further action' (Hermann, 2001, p. 71). Therefore, it could be expected from Putin to make an alternative set of actions possible for similar situations, if they recur. In parallel to this, Putin on several occasions declared his dissatisfaction regarding the consequences of the intervention. Besides, although Medvedev was in power for three years by then, Putin was still powerful within the circles of the Kremlin and was able to suppress Medvedev in his last year of presidency and became the 'predominant leader' even before he was elected.

Putin was disappointed when he heard that imposing of no-flyzone, which turned out to be a full-scale military attack by Western powers. Putin would regard that the military involvement of Western powers, France, UK, USA, and Canada, meant that Western encirclement took one step further to Russia. Therefore, it could be stated that Putin's 
feedback was negative and he would push for reconsideration. Putin publicly criticized the decision, by saying that "he was "dumbfounded" over how easy decisions are made to use force against countries' and concerning that the imposing of 'no-fly zone' which was agreed in UNSC has been turned out to be a full-scale military attack he said: 'Don't you think that there is a serious controversy between words and practice of international relations?' (RIA Novosti, April, 2012). Besides regarding the consequences of the intervention he stated that: "Nearly the entire Gaddafi family was killed. His corpse was shown on all world TV channels. It's impossible to look at it without disgust" (RIA Novosti, October 2012). Putin made it very clear that the intervention was not a good idea, concerning its consequences and its way of conduct. In response, Medvedev openly rejected Putin's position and publicly stated that he finds Putin's declarations unacceptable while underlining the crimes against humanity committed by the Gaddafi regime (Levy and Shanker, 2011).

Putin did not wait too long to make the move, which would render him the 'predominant leader' in the foreign policy decision-making mechanism. Security Council of Russia was set up by Yeltsin to replace the Security Council of the USSR in 1992. The Constitution states that the President picks the members of the Security Council (Constitution of Russian Federation, Article 83). Security Council was thought of as an advisory body in which different factions can get together and discuss state affairs face to face. However, it should be noted that the head of the Security Council is Nicolai Patrushev, whose KGB career and Silovik affiliation is widely known. In May 2011, the authorities of this organization were increased by a presidential decree. The organization, since then, has been able to supervise the military administration regarding national and international security matters (Medvedev, 2011b). 
Therefore, it was a move by Putin to increase the power of Siloviki within the Kremlin through which he became the 'predominant leader' even before he became president.

The foreign policymaking mechanism in Russia faced another decision-making point in Syria upon the international outcry for a military intervention to Syria upon the findings of chemical weapon usage by the Assad regime. Back in August 2012, Obama stated that he would not consider military intervention in Syria but he suggested that the usage of chemical weapons 'would change his calculus' (The White House, 2012). In April 2013, US Secretary of State Chuck Hagel states that 'the US now believes that sarin gas was used in Syria by the regime' (Armbruster, 2013). Regarding that, Britain and France informed the UN Secretary that there is credible evidence that Syria has used chemical weapons on more than one occasion since December (Lynch and Karen, 2013). After the leakage of hundreds of videos of people dying as a result of what seems to be chemical weapons allegedly used by Assad forces in the Ghouta region of Damascus, while the UN observer mission was on duty, created an outrage in the international community as US sources verified that the chemical weapons have been used by the Assad regime (Shachtman, 2013). The Russian response to this crisis has evolved within the dynamics of foreign policymaking orchestrated by Putin, who became the 'predominant leader'.

It is noteworthy that, unlike what had happened concerning Libya, when the split between the ideas of Medvedev and Putin was revealed within their public speeches; Lavrov, Putin, and Medvedev regarding Syria held a similar stance. In that sense, it can be suggested that the authoritative decisionmaking unit was 'predominant leader' is Putin. Days after the issue erupted, Putin stated in a press conference that the Syrian government had to defend itself against terrorists and 
the chemical weapon issue is a provocation of opposition forces (Putin, 2013). Lavrov, on the other hand, stated that he doesn't believe that it was Assad forces that used chemical weapons (Lavrov, 2013). It is noteworthy that the statements were in line with what the information minister El-Zabi said on TV had, he suggested that: "We have never used chemical weapons in Syria in any form, be it liquid or gas" (Ria Novosti, August 2013).

With such discourse and action, Russia managed to work out a resolution, which would secure the continuation of the Assad regime. Upon the talks between Russia and the USA, it was agreed that the UN and OPCW (Organization for the Prohibition of Chemical Weapons) work together to destruct the chemical weapons, which the Syrian regime is known to hold. It was a momentous event; when Lavrov, after the adoption of the UNSC Resolution 2118, stressed to the point that the Resolution 'does not allow for any automatic use of force or measures of enforcement for compliance failures by Syria and Security Council would have to "carefully" consider any enforcement decisions' (Yoon, 2013). This can demonstrate how delicate Russian Foreign Policy became regarding the intervention after Putin established his control over the foreign policy apparatus.

Having been dissatisfied with the intervention in Libya, Putin sought further influence within the foreign policy mechanism of Russia. Therefore, before moving to President's Office he managed to work out a constitutional change, which would secure Siloviki control. Putin's inauguration to presidency rendered the intervention to Syria, virtually impossible. 
Table 5: Application of Decision-Unit Framework to Syria Case

\begin{abstract}
An occasion for Decision: The eruption of the alleged chemical weapons use by the Assad forces.
\end{abstract}

The emergence of Authoritative Decision-Making Unit: 'predominant leader'

Process Outcome: Publicly denying the chemical weapons use by Assad forces and holding a firm stance against the idea of military intervention. In conclusion: UNSC Resolution 2118, which would not enable military involvement.

\title{
Conclusion
}

This paper addressed the question of why did Russian Federation enabled the intervention in Libya but did not do the same for Syria. I argued that the main factor was the alteration in the foreign policy decision-making mechanism, which was made possible by Putin. This research required a comparative analysis of Russian foreign policy decision-making mechanisms that emerged concerning Syria and Libya cases, which I dealt with the 'decision-unit framework,' which provided a sophisticated set of tools to analyze these two cases coherently. The framework enables to predict the policy outcome concerning the characteristic features of the emerged 'authoritative decision-making unit' upon the occasion for decision.

It should be noted that Russia was the key actor when the international community was seeking a resolution for the 
problems in Libya and Syria respectively. Russia was the main actor, which could block the initiatives for action through UNSC channels with its veto power. Therefore, the western camp in the UNSC could further its actions only to the point where Russia approves. In other words, the UNSC Resolutions, in a sense, reflecting how much compromise Russia could make.

Considering these points, it was revealed within this article that Russia's Libya decision was made within the dynamics of "coalition of autonomous actors". While the UNSC 1970 Resolution, in which Russia secured a provision that prevents further military action was a product of 'lopsided compromise'; the UNSC 1973 Resolution was made possible when Medvedev's position prevailed as opposed to Putin and Russia enabled the military intervention to Libya. The story begins after this point. Putin was not satisfied with what has happened at all. Therefore, he pushed for further consideration of the way the foreign policy of Russia is conducted. Concerning this, the constitution was amended for increasing the authority of the Security Council, which ensures the Siloviki control over military and bureaucracy regarding security matters. Moreover, when Putin came to power he utilized being 'predominant leader' through which he utilized the foreign policy apparatuses to the point where Lavrov has stressed the point that the UNSC Resolution 2118 could not enable the use of force against Syria. 


\section{Bibliography}

Abdel-Baky, M. (2011). Libya Protest Over Housing Enters Its Thirt Day. Ahramonline. Avalilable at https://english.ahram.org.eg/NewsContent/2/8/4032/World/R egion/Libya-protest-over-housing-enters-its-third-day.aspx accessed from on 15.11.2021.

Allison, G. (1969). Conceptual Models and the Cuban Missile Crisis, The American Political Science Review, 63 (3), 689-718.

Armbruster, B. (2013) How We Got Here: A Timeline Of The Syria Chemical Weapons Saga. Thinkprogress. 28 August 2013 https://archive.thinkprogress.org/how-we-got-here-atimeline-of-the-syria-chemical-weapons-saga-ead5d39642cc/ accessed from on 15.11.2021

Ataman, M. (2012). Suriye'de iktidar Mücadelesi: Baas Rejimi, Toplumsal Talepler ve Uluslararası Toplum (Report No. 6), SETA. Available at http://file.setav.org/Files/Pdf/20121126132435_setasuriye_de_iktidar_mucadelesi.pdf accessed from on 15.11.2021.

Bremmer, I. and Charap, S. (2007). The Siloviki in Putin's Russia: Who They Are and What They Want, The Washington Quarterly, 33 (1), 83-92.

Cadier, D. and Light, M. (2015). Conclusion: Foreign Policy as the Continuation of Domestic Politics by Other Means, In Russia's Foreign Policy: Ideas, Domestic Politics and External Relations, ed. D. Cadier and M. Light, (p. 204-216), Basingstoke: Palgrave Macmillan.

Clunan, A. L. (2009). The Social Construction of Russia's Resurgence Aspirations, Identity, and Security Interests, Baltimore: The John Hopkins University Press. 
Constitution of Russian Federation, Article 83, http://www.constitution.ru/en/10003000-01.htm accessed from on 15.11.2021.

Duncan, P. J. S. (2013). Batman and Robin? Exploring foreign policy differences between Putin and Medvedev during the Medvedev presidency, CEPSI: Working Paper.

Ermath, F. (2009). Russian Strategic Culture in Flux: Back to the Future? In Strategic Culture and Weapons of Mass Destruction, edited by Jeannie L. J., Kerry M. Kartchner, and Jeffrey A. Larsen, Palgrave Macmillan.

Feinstein, S. G. \& Pirro E. B. (2021). Testing the world order: strategic realism in Russian foreign affairs, International Politics, 58, 817834.

Forsberg, Tuomas at all. (2014). Status and emotions in Russian Foreign Policy. Communist and Post-Communist Studies, 47(34), 261-268.

Hermann, M. G. \& Hermann, C. F. (1982). A Look Inside the Black Box: Building on a Decade of Research, In G. Hopple, Biopolitics, Political Psychology and International Politics, (pp. 1-36), New York: St. Martin's Press.

Hermann, M. G. \& Hermann, C. F. (1989). Who Makes Foreign Policy Decisions and How: An Empirical Inquiry. International Studies Quarterly. 33 (4), 361-387.

Hermann, M. G. (2001). How Decision Units Shape Foreign Policy: A Theoretical Framework. International Studies Review, 3 (2): 4781.

Hermann, M. G., Hermann, C. F. \& Hagan, J. D. (1987). How Decision Units Can Shape Foreign Policy Behaviors, In New Directions in the Study of Foreign Policy ed. by J. N. Rosenau, Hermann, R. F. and Kegley, C. W., (p. 309-336), London: Allen Unwin.

Hill, F. and Gaddy C. (2013). Mr. Putin: Operative in the Kremlin, Washington DC: Brookings Institute. 
Holsti, O. R. (1959). The 1914 Case, The American Political Science Review, 59 (3), 365-378.

Hopf, T. (2016). 'Crimea is ours': A discursive history. International Relations, 30(2), 227-255.

Janis, I. (1972). Victims of groupthink: A psychological study of foreign-policy decisions and fiascoes, Boston: Mifflin.

Kanet, R. (2012). Russia in the new international order: Theories, arguments and debates, International Politics, 49 (4), 393-399.

Kropatcheva, E. (2012). Russian foreign policy in the realm of European security through the lens of neoclassical Perspective, International Politics, 49 (4), 30-40.

Larson, D. W. and Shevchenko A. (2010). Status Seekers: Chinese and Russian Responses to U.S. Primacy, International Security, 34 (10), 63-59.

Lavrov, S. (2013). Speech and answers to questions from the mass media by Russian Foreign Minister Sergey Lavrov during the press conference on the topic of chemical weapons in Syria and the situation around the Syrian Arab Republic, Moscow, 26

August

2013.

http://www.mid.ru/bdomp/brp_4.nsf/e78a4807of128a7b4325 6999005bcbb3/7426df843775abd244257bd500611d38!Open Document accessed from on 15.11.2021.

Leites, N. C. (1953). A Study of Bolshevism, Santa Monica, CA: Rand Corp.

Levy, J. Clifford and Shanker, Thom (2011). In Rare Split, Two Leaders in Russia Differ on Libya, NY Times. https://www.nytimes.com/2011/03/22/world/europe/22russia. $\mathrm{html}$ adresinden accessed from on 15.11.2021.

Libya opposition launched council (2011). Al-Jazeera. 28 February 2011. https://www.aljazeera.com/news/2011/2/28/libyaopposition-launches-council accessed from on 15.11.2021. 
Lynch, A. (2009). The Realism of Russia's Foreign Policy, Europe-Asia Studies, 53 (1), 7-31.

Lynch, C. (2011). UN votes to impose sanction on Gaddafi, Washington Post.

http://www.washingtonpost.com/wpdyn/content/article/2011 /02/26/AR2011022603386.html accessed from on 15.11.2021.

Lynch, C. and Karen D. (2013). Britain, France claim Syria used chemical weapons, Washington Post. http://www.washingtonpost.com/world/nationalsecurity/britain-france-claim-syria-used-chemicalweapons/2013/04/18/f17aze7c-a82f-11e2-a8e25b98cb59187f_story.html accessed from on 15.11.2021.

Mearsheimer, J. J. (2014). Why the Ukraine Crisis Is the West's Fault: The Liberal Delusions That Provoked Putin, Foreign Affairs, 93 (5), 77-89.

Medvedev, D. (2011a). Executive order on fulfilment of UN Security Council Resolution 1973. http://eng.kremlin.ru/news/2703 accessed from on 15.11.2021.

Medvedev, D. (2011b). Prezident Rossii vystupilna otkrytii Vsemirnogo ekonomicheskogo foruma, Kremlin.ru, http://kremlin.ru/events/president/news/10163 adresinden accessed from on 15.11.2021.

Medvedev, D. (2011C). Utverzhdeno novoye Polozheniye o Sovete Bezopasnosti Rossii, President of Russia http://kremlin.ru/acts/11171\#sel= accessed from on 15.11.2021.

Mintz, A. (2005). Applied Decision Analysis: Utilizing Poliheuristic Theory to Explain and Predict Foreign Policy and National Security Decisions, International Studies Perspectives, 6 (1), 9498.

Morozov, V. (2015). Russia's Postcolonial Identity A Subaltern Empire in a Eurocentric World, London: Palgrave Macmillan. 
Putin, V. (2013). Otvetynavoprosyzhurnalistov, kremlin.ru, http://kremlin.ru/news/19113 accessed from on 15.11.2021.

Reder, J. M. (2013). The Medvedev Years: An Examination of the External Forces \& Internal Dynamics Affecting the Kremlin's Foreign Policy Decisions, University of Hull. https://hydra.hull.ac.uk/assets/hull:7197a/content accessed from on 15.11.2021.

Renz, B. (2006). Putin's Militocracy? An Alternative Interpretation of Siloviki in Contemporary Russian Politics, Europe-Asia Studies, 58 (6), 903-914.

Ria Novosti. (2012, April). Putin says 'dumbfounded' over NATO operation in

Libya. http://en.ria.ru/russia/20110427/163739739.html accessed from on 15.11.2021.

Ria Novosti. (2012, October). Putin condemns footage showing Gaddafi death. http://en.ria.ru/world/20111026/168144832.html accessed from on 15.11.2021.

Ria Novosti. (2013). Syrian Minister Rejects Chemical Attack Reports. http://en.ria.ru/world/20130825/182952149.html accessed from on 15.11.2021.

Rossiya 24 TV (2011). Russia's Putin Warns Against 'External Interference' in North Africa, Middle East, World News Connection.

Security Council of Russia (2011). Deyatel'nost'. http://www.scrf.gov.ru/news/19/index5.html accessed from on 15.11.2021.

Shachtman, N. (2013). Exclusive: Intercepted Calls Prove Syrian Army Used Nerve Gas, U.S. Spies Say, Foreign Policy. http://thecable.foreignpolicy.com/posts/2013/08/27/exclusive _us_spies_say_intercepted_calls_prove_syrias_army_used_n erve_gas accessed from on 15.11.2021. 
Snyder, J. (1977). The Soviet Strategic Culture: Implications for Limited Nuclear Options, Santa Barbara: Rand Corporation.

Solomon, J. and Spindle, B. (2011). Syria Strongman: Time for 'Reform, Wall Street Journal. http://online.wsj.com/news/articles/SB1000142405274870483 2704576114340735033236 accessed from on 15.11.2021.

Stern, E. (2006). Contextualizing and Critiquing the Poliheuristic Theory, The Journal of Conflict Resolution, 48 (1), 105-126.

Toal, G. (2017). Near Abroad: Putin, the West and the Contest over Ukraine and the Caucasus, New York: Oxford University Press.

Tsygankov, A.P. (2016). Russia's Foreign Policy: Change and Continuity in National Identity. Lanham, MD: Rowman and Littlefield.

The White House (2012). Remarks by the Presidentto the White House Press Corps. $20 \quad$ August 2012. https://obamawhitehouse.archives.gov/the-pressoffice/2012/08/20/remarks-president-white-house-press-corps accessed from on 15.11.2021.

Yeltsin, B. (2010). 'KonstitutsiyaRossii.' ArkhivKremlina. http://archive.kremlin.ru/articles/ConstMain.html accessed from on 15.11.2021.

Yoon, S. (2013) Syria cemical weapons resolution passed by UN security council. Mint. 28 September 2013. https://www.livemint.com/Politics/7AktxpHaDnUunwfxO3jQ1 $\mathrm{J} /$ Syria-chemicalweapons-resolution-passed-by-UN-securitycoun.html accessed from on 15.11.2021.

Ziegler, C. (2012). Conceptualizing Sovereignty in Russian Foreign Policy: Realist and Constructivist Perspectives, International Politics, 49 (4), 400-417. 